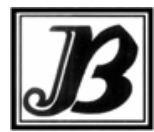

J. bio-sci. 20: 153-160, 2012

ISSN 1023-8654

http://www.banglajol.info/index.php/JBS/index

\title{
CHEMICAL INVESTIGATION AND MICROBIAL ACTIVITY OF TINOSPORA CORDIFOLIA MIERS
}

\author{
A H Molla, M G Zakaria, M T H Molla, M T Alam, M S Ahsan* \\ Department of Applied Chemistry and Chemical Engineering \\ University of Rajshahi, Rajshahi- 6205, Bangladesh
}

\begin{abstract}
Context: Plants have been used in treating human diseases for thousands of years. Medicinal plant drug discovery continues to provide new and important leads against various pharmacological targets including cancer, malaria, HIVIAIDS, Alzheimer's, and pain.

Objectives: The chemical investigation, antimicrobial activity and toxicity of the active principles isolated from the plant.

Materials and Methods: The rectified spirit extract of the fresh stem of the plant Tinospora cordifolia was fractionated using standard chromatographic techniques to afford several fractions. The fraction TC-1 was purified by crystallization and screened. FTIR, ${ }^{1} \mathrm{H}$ NMR, ${ }^{13} \mathrm{C}$ NMR spectral analyses were performed to characterize the compound. The antibacterial and antifungal activities of TC-1 were observed by "Disc diffusion method" against a number of pathogenic bacteria and fungi. Standard antibiotics "Kanamycin" (30 $\mathrm{gg} / \mathrm{disc})$ and "Fluconasol" (500 $\mathrm{\mu g} / \mathrm{disc})$ were used respectively for comparison. The minimum inhibitory concentration (MIC) of the compound TC-1 was carried out by the "Serial Dilution Technique". The compound also showed significant activity against the brine shrimp nauplii.

Results: The compound TC-1 showed promising antibacterial and antifungal activities against all tested organisms. The minimum inhibitory concentration (MIC) of TC-1 against Bacillus megaterium and Salmonella typhi-A was found to be $128 \mu \mathrm{g} / \mathrm{ml}$ in nutrient broth medium. The value of medium lethal concentration, $\mathrm{LC}_{50}(9.34 \mathrm{\mu g} / \mathrm{ml})$ indicated the high toxic effect of the compound TC-1.
\end{abstract}

Conclusion: It may be concluded that the compound TC-1 is an alkaloid having significant activities.

Key words: Chromatography, Antibacterial activity, Antifungal activity, Toxicity, Minimum inhibitory concentration, Brine shrimp lethality bioassay.

\section{Introduction}

Plant kingdom serves as the sources of food, clothing, shelter, fuel and medicine Fuller et al. (1967) and it is expected that the treasure of plant materials will give lead compounds to relief diseases like diabetes, cancer, AIDS, etc. The medicinal value of plants captured the attention of people millennia ago Laetsch (1979). It is estimated that thousands of different species have been used as medicine by various peoples of the world Lewington (1990). Of the many medicinal plants that have been used since ancient time, many have yielded most useful drugs that are very much in use in current medicine. Emetine, still considered an important medicine for Amoebiasis, was isolated from Cephaelis ipecacuanha Burger (1960). It is used in Brazil and Far-East for dysentery and diarrhea. Morphine Burger (1960), the most important natural analgesic was isolated from opium poppy. Reserpine used as a hypotensive drug and a tranquilizer has come from the plant Rauwolfia serpentina Muller et al. (1952). The root and stem of Tinospora cordifolia are

*Corresponding author E-mail:ahsanshameen@yahoo.com 
prescribed in combination with other drugs as an antidote snakebite and scorpion sting (Nadkarni et. al 1976, Kritikar et. al (1980). It is considered to be a common remedy for mental illness and snake bite in the Indian sub-continent. Many other plant products used in medicine include atropine Burger (1960) from Atropa belladonna, ephedrine Hesse et al. (1966) from Ephedra vulgaris and strychnine from Nuxvomica. Today it has become possible to synthesize drugs, which act very selectively and in most cases the side effects of such drugs are said to be substantially less than their ayurvedic counterparts. But all over the world, and particularly in the third world countries, various medicinal plants rationally used in the treatment of diseases because of the effectiveness and low price. The prospect of use of plant constituents as remedy for diseases in Bangladesh is very promising. Tinospora cordifolia belongs to the plant family Minispermaceae and this family is known to produce diverse classes of pharmacologically active compounds. T. cordifolia, mentioned in Ayurvedic literature as a constituent of several compound preparations. It is used in general disability, dyspepsia, fevers, and urinary diseases. Ethyl acetate extract of $T$. cordifolia had central nervous system depressant and hypoglycemic activities Mahajan et al (1985). Alcoholic extract of the stem shows activity against Escherichia coli. It has been suggested that the action of the drug is due to its favorable effect on the endogenous insulin secretion; glucose uptake and inhibition of peripheral glucose release Gupta et al (1967). This stem is prescribed in combination with other drugs as an antidote to snake-bite. It is also a valuable nutrient, when there is intestinal irritability and inability to digest any kind of food. The leaves are rich in protein and fairly reach in calcium and phosphorus, and can be used as fodder. A tincture of the leaves is used for the treatment of gout Hesse et al. (1966). Dried and powdered fruit, mixed with honey is used as a tonic and also in the treatment of jaundice and rheumatism. The root is a powerful emetic and used for visceral obstructions, its watery extract is used in the treatment of leprosy Rao et. al (2000). Tinospora is a genus in Menispermaceae family in which a lot of work has been performed and few different compounds have been isolated from different members of this family but little work has been carried out on Tinospora cordifolia. Apart from the above observations, we have been interested to isolate pure compounds as well as to observe their antimicrobial and antifungal activities.

\section{Materials and Methods}

The chemicals used in this study were purchased from BDH Chemical Ltd., England and Merck, Germany and were purified by standard methods prior to use. Infrared (IR) spectrum was recorded with Pye-unicam SP3 -300 Spectrophotometer (KBr), NMR $\left({ }^{1} \mathrm{H}, 500 \mathrm{MHz} ;{ }^{13} \mathrm{C}, 400 \mathrm{MHz}\right)$ spectra were obtained in pyrd5 on a JEOL-AX-500 and JEOL-JNM AX 400 spectrometers, respectively. The chemical shifts are given in $\delta$ values.

Collection of the plant: Fresh stem of Tinospora cordifolia Miers were collected from the adjoining areas of Rajshahi University (Bangladesh) Campus during the month of January-February, 1997.

Preparation and extraction of plant materials: The stems of the plant were cut into small pieces and made paste using morter and pestle. It was then extracted with rectified spirit and the solvent was evaporated off under normal pressure and temperature to obtain a gummy mass.

Isolation and purification of compounds: The crude rectified spirit extract was subjected to alumina column for fractionation. The sample was successively eluted with $n$-hexane, $n$-hexane with increasing portions of petroleum ether, ethyl acetate, and finally with methanol. A number of color bands were observed during the development of the columns. Different fractions were obtained and the fractions were combined on the basis of their preliminary TLC examination. Only the fractions designated as TC-1 were collected and the solvent of the combined fractions was evaporated off under reduced pressure to obtain a crystalline mass which after re-crystallization needle shaped compound, TC-1 having melting point $187^{\circ} \mathrm{C}$ was obtained. 
Source of Test Microorganisms: To determine the antibacterial and antifungal activity of compound TC-1, a number of organisms were collected from "The International Centre for Diarrhoeal Disease Research, Bangladesh (ICDDR,B)."

Antibacterial and antifungal screening of TC-1: The antibacterial and antifungal activities of TC-1 were determined using "Disc diffusion method" Bauer et al. (1966) against a number of pathogenic bacteria (Table 1) and fungi (Table 2).

Determination of minimum inhibitory concentration (MIC): The minimum inhibitory concentration (MIC) of the compound TC-1 was determined against gram positive Bacillus megaterium and gram negative Salmonella typhi-A. The test was carried out by the "Serial Dilution Technique" Reiner (1982) using nutrient broth medium.

Brine Shrimp Lethality Bioassay: Brine shrimp lethality test is a recent development in the bioassay for the bioactive compounds. Bioactive compounds are almost always toxic in high dose. In this method, sea water was kept in the shrimp tank where constant oxygen supply was carried out and constant temperature (around $37^{\circ} \mathrm{C}$ ) was maintained. Two days were allowed for the shrimp to hatch to mature nauplii (larva). The hatched shrimps were attracted to the lamp on the other side of the tank which is divided through a perforated dam.

\section{Results and Discussion}

The rectified spirit extract showed at least three components $\left(R_{f}=0.40,0.54\right.$, and 0.74$)$ on thin layer chromatographic plates with the solvent system petroleum ether: ethyl acetate (1: 2). Through the column chromatography different fractions were obtained and the fractions were combined on the basis of their preliminary TLC examination to give combined fractions A, B, C, D, E, and F. Among these fractions, fraction A gave no spot on TLC and was discarded. The residue from fraction B didn't give any discrete spot with different solvent system and tailed badly and was not worked out further. The fraction $C$ showed two spots $\left(R_{f}=0.67\right.$ and 0.58$)$. The residue was subjected to a small chromatographic column using ethyl acetate : toluene (1:4) and two eluents were collected and the solvent was evaporated off under reduced pressure to get insufficient quantities for further work. Fraction $D$ showed two spots $\left(R_{f}=0.53\right.$ and 0.75$)$ on TLC plate using petroleum ether: ethyl acetate (1:1) as solvent system. It was further subjected on mini column chromatography using petroleum ether: ethyl acetate (1:1). The two eluents were collected and the solvent was evaporated off under reduced pressure to get two components designated as TC-1 and TC-2. The component TC-1 was crystalline but the component TC-2 was non-crystalline and also the product was minor. The crude compound TC-1 was purified by re-crystallization and the isolated product was tested in different solvent systems for checking its purity. The compound showed a single spot on TLC examination.

\section{Characteristics of TC-1:}

The compound formed colorless needles from n-hexane and ethyl acetate and the melting point was $178^{\circ} \mathrm{C}$. It was highly soluble in ethyl acetate and chloroform, insoluble in n-hexane, and petroleum ether but sparingly soluble in ethanol and diethylether. It gave positive test for ketone, tertiary amine, alcohol, ester, unsaturation, alkaloid and negative test for carbohydrate, phenol and hydrocarbon Finar (1975). In this study, FTIR, ${ }^{1} \mathrm{H}-\mathrm{NMR},{ }^{13} \mathrm{C}-\mathrm{NMR}$ spectral analyses were performed to characterize the compound TC-1. 
$\underline{\mathbb{R}\left(\mathrm{KBr}, \mathrm{cm}^{-1}\right)}:$

The infrared spectrum of the compound showed nine characteristic bands in the functional group region at 3509 (OH stretching), 2993, 2938, 2771 (C-H stretching), 1705 (>C=0 stretching), 1502 (NH stretching), 1150 (CH stretching)

\section{${ }^{13} \mathrm{C}$ NMR (Pyrd 5$)$ :}

$>\mathrm{C}=\mathrm{O}$ at $176.02,174.41,174.36$, and $173.08 \mathrm{ppm}$

$\mathrm{ArCH}$ at $144.63,140.86,138.08$, and $130.55 \mathrm{ppm}$

$\mathrm{ArC}$ at 126.59 and $126.49 \mathrm{ppm}$

$=\mathrm{CH}$ at 109.75 and 109.72 (downfield signals may be due to the presence of neighboring electronegative group such as $\mathrm{OH}$ )

$=\mathrm{CH}$ at $74.47,71.56$ and 71.47 (olefinic $\mathrm{CH}$ )

$-\mathrm{CH}$ at $52.65,50.53,47.53,47.59,46.88,45.09$ and 44.60 (aliphatic)

$=\mathrm{CH}_{2}$ at 81.97 and $81.90 \mathrm{ppm}$ (olefinic $=\mathrm{CH}_{2}$ )

$-\mathrm{CH}_{2}$ at $42.26,42.15,41.79,38.33,36.93,35.52,27.19,27.04,18.27$, and 17.60, aliphatic $\mathrm{CH}_{2}$ )

$-\mathrm{CH}_{3}$ at 28.93, 28.41, 24.98, and $23.87 \mathrm{ppm}$

\section{${ }^{1} \mathrm{H}$ NMR (Pyrd5):}

$7.73(1 \mathrm{H}, \mathrm{S}, \mathrm{ArH}), 7.65 \sim 7.67(3 \mathrm{H}, \mathrm{m}, \mathrm{ArH}), 6.70\left(2 \mathrm{H}, \mathrm{dd}, \mathrm{J}=1.3\right.$ and $12.2 \mathrm{~Hz}$, terminal $=\mathrm{CH}_{2}$ olefinic), 6.51 $(1 \mathrm{H}, \mathrm{dd}, \mathrm{J}=2.2$ and $9.6 \mathrm{~Hz},=\mathrm{CH}), 6.43(1 \mathrm{H}, \mathrm{dd}, \mathrm{J}=6.4$ and $9.6 \mathrm{~Hz},=\mathrm{CH}), 5.99(1 \mathrm{H}, \mathrm{dd}, \mathrm{J}=5.1$ and $15.3 \mathrm{~Hz}$, $=\mathrm{CH}$ two olefinic terminal), $5.92(1 \mathrm{H}, \mathrm{dd}, \mathrm{J}=5.1$ and $15.3 \mathrm{~Hz},=\mathrm{CH}), 5.45(1 \mathrm{H}, \mathrm{dd}, \mathrm{J}=5.1 \mathrm{~Hz},=\mathrm{CH}$, Five olefinic $=\mathrm{CH}), 5.26\left(2 \mathrm{H}\right.$, s, terminal olefinic $\left.\mathrm{CH}_{2}\right), 2.94 \sim 2.87\left(3 \mathrm{H}, \mathrm{m}, \mathrm{CH}_{2}\right), 2.60\left(2 \mathrm{H}, \mathrm{dd},=\mathrm{CH}_{2}\right), 2.51\left(2 \mathrm{H}, \mathrm{t},=\mathrm{CH}_{2}\right)$, $2.34\left(2 \mathrm{H}, \mathrm{s}, \mathrm{CH}_{2}\right), 1.98 \sim 2.14\left(10 \mathrm{H}, \mathrm{m}, \mathrm{CH}_{2}\right), 1.75 \sim 1.85\left(4 \mathrm{H}, \mathrm{m}, \mathrm{CH}_{2}\right), 1.52(4 \mathrm{H}, \mathrm{s}$, either $\mathrm{NH}$ or $\mathrm{OH}$, or both protons), $1.33\left(6 \mathrm{H}, \mathrm{s}, 2 \times \mathrm{CH}_{3}\right), 1.32\left(3 \mathrm{H}, \mathrm{s}, \mathrm{CH}_{3}\right), 1.31\left(3 \mathrm{H}, \mathrm{s}, \mathrm{CH}_{3}\right)$.

From the above spectral evidences it can be concluded that the compound is an alkaloid containing 37 carbon atoms with the 52 hydrogen along with secondary or tertiary nitrogen atoms and several $\mathrm{OH}$ groups in the molecule. More spectral data e.g., GC Mass, HSCOSY, HSQC, and HMBC are needed for complete structure elucidation.

Antibacterial screening: The antibacterial activities of TC-1 were determined by measuring the diameter of zone of inhibition in term of $\mathrm{mm}$. The results are shown in Table 1. The compound TC-1 showed a significant antibacterial activity against a wide range of gram-positive and gram-negative bacteria. The antibacterial activity exhibited by the test sample was compared with that produced by a standard antibiotic Kanamycin. The diameters of zone of inhibition produced by TC-1 against Salmonella typhi-A, Shigella flexeneriae, Bacillus megaterium and Bacillus subtilis were found to be 10,10,11, and 09, respectively. But this compound showed little or no activity against other bacteria used. 
Table 1. In vitro antibacterial activity of the compound TC-1

\begin{tabular}{|c|c|c|}
\hline \multirow[t]{2}{*}{ Bacterial Strains } & \multicolumn{2}{|c|}{$\begin{array}{l}\text { Zone of inhibition measured in } \mathrm{mm} \text { after } 24 \text { hours of } \\
\text { incubation }\end{array}$} \\
\hline & Kanamycin $30 \mu \mathrm{g} / \mathrm{disc}$ & TC-1 $200 \mu \mathrm{g} / \mathrm{disc}$ \\
\hline Bacillus megaterium & 32 & 11 \\
\hline Bacillus subtilis & 32 & 09 \\
\hline Sarcina lutea & 31 & 08 \\
\hline Bacillus cereus & 30 & 00 \\
\hline Staphylococcus aureus & 32 & 07 \\
\hline Staphylococcus sp. & 32 & 00 \\
\hline Salmonella typhi-A & 32 & 10 \\
\hline Shigella dysenteriae & 31 & 08 \\
\hline Escherichia coli & 30 & 00 \\
\hline Shigella flexeneriae & 32 & 10 \\
\hline Shigella boydii & 32 & 00 \\
\hline Klebsiella sp. & 32 & 11 \\
\hline
\end{tabular}

Antifungal screening: The antifungal activity of the compound TC-1 had been observed against eleven fungi of which nine are plant fungi and the rest two are human fungi (Table 2). In this experiment the compound showed significant activity against Fusarium sp, Bipolaris sorokiniana, Aspergillus terreus, Aspergillus flavus, and Trichoderma viride. But this compound showed little or no activity against Penicillum sp., Botryodiplodia theobromae, Candida albicans, and Trichophyton sp. The antifungal activity exhibited by the test sample was compared with that produced by a standard antibiotic Fluconasol.

Table 2. In vitro antifungal activity of the compound TC-1

\begin{tabular}{|c|c|c|c|}
\hline & \multirow[t]{3}{*}{ Name of the Fungi } & \multicolumn{2}{|c|}{ Zone of inhibition measured in $\mathrm{mm}$} \\
\hline & & Fluconasol & TC-1 \\
\hline & & $500 \mu \mathrm{g} / \mathrm{disc}$ & $200 \mu \mathrm{g} / \mathrm{disc}$ \\
\hline \multirow{9}{*}{$\begin{array}{c}\text { Plant } \\
\text { Fungus }\end{array}$} & Trichoderma viride & 30 & 12 \\
\hline & Fusarium sp. & 0 & 30 \\
\hline & Aspergillus terreus & 0 & 12 \\
\hline & Selerotium rolfsii & 0 & 8 \\
\hline & Aspergillus flavus & 0 & 10 \\
\hline & Penicillum sp. & 0 & 0 \\
\hline & Bipolaris sorokiniana & 30 & 14 \\
\hline & Botryodiplodia theobromae & 0 & 0 \\
\hline & Aspergillus niger & 10 & 7 \\
\hline \multirow{2}{*}{$\begin{array}{l}\text { Human } \\
\text { Fungus }\end{array}$} & Candida albicans & 0 & 0 \\
\hline & Trichophyton sp. & 0 & 0 \\
\hline
\end{tabular}




\section{Minimum Inhibitory Concentration (MIC):}

The minimum inhibitory concentration (MIC) of the compound TC-1 was determined against Bacillus megaterium and Salmonella typhi-A (Tables $3 \& 4$, respectively). The MIC of TC-1 against both of Bacillus megaterium and Salmonella typhi-A was $128 \mu \mathrm{g} / \mathrm{ml}$ when tested in nutrient broth medium. No inhibition was recorded in test tubes containing compound lower than the above concentration. Growth of the organism was observed in the test tube $\mathrm{C}_{1}$ and contents of the test tubes $\mathrm{C}_{\mathrm{M}}$ and $\mathrm{C}_{\mathrm{s}}$ were clear. From table 3 it was found that the MIC of the pure compound TC-1 against Bacillus megaterium was $128 \mu \mathrm{g} / \mathrm{ml}$. From table 4 , it was found that the MIC of the pure compound TC-1 against Salmonella typhi-A was $128 \mu \mathrm{g} / \mathrm{ml}$.

Table 3. MIC of the compound TC-1 against Bacillus megaterium

\begin{tabular}{|c|c|c|c|c|c|}
\hline $\begin{array}{c}\text { Test tube } \\
\text { no. }\end{array}$ & $\begin{array}{l}\text { Nutrient broth } \\
\text { medium added } \\
(\mathrm{ml})\end{array}$ & $\begin{array}{c}\text { Diluted solution of } \\
\text { the compound TC-1 } \\
(\mu \mathrm{g} / \mathrm{ml})\end{array}$ & $\begin{array}{l}\text { Inoculum added } \\
(\mu \mathrm{l})\end{array}$ & Observation & $\begin{array}{c}\mathrm{MIC} \\
\mu \mathrm{g} / \mathrm{ml}\end{array}$ \\
\hline 1 & 1 & 512 & 10 & NG & \multirow{13}{*}{128} \\
\hline 2 & 1 & 256 & 10 & $N G$ & \\
\hline 3 & 1 & 128 & 10 & NG & \\
\hline 4 & 1 & 64 & 10 & G & \\
\hline 5 & 1 & 32 & 10 & G & \\
\hline 6 & 1 & 16 & 10 & G & \\
\hline 7 & 1 & 8 & 10 & $G$ & \\
\hline 8 & 1 & 4 & 10 & G & \\
\hline 9 & 1 & 2 & 10 & G & \\
\hline 10 & 1 & 1 & 10 & G & \\
\hline $\mathrm{Cs}_{\mathrm{s}}$ & 1 & 512 & 00 & $G$ & \\
\hline$C_{1}$ & 1 & 0 & 10 & G & \\
\hline $\mathrm{C}_{\mathrm{M}}$ & 1 & 0 & 00 & G & \\
\hline
\end{tabular}

G=Growth; NG= No Growth; No. of cells: $10^{7} \mathrm{celll} / \mathrm{ml}$

Table 4. MIC of the compound TC-1 against Salmonella typhi-A

\begin{tabular}{cccccc}
\hline $\begin{array}{c}\text { Test tube } \\
\text { no. }\end{array}$ & $\begin{array}{c}\text { Nutrient broth } \\
\text { medium added } \\
(\mathrm{ml})\end{array}$ & $\begin{array}{c}\text { Diluted solution } \\
\text { of the compound } \\
\text { TC-1 }(\mu \mathrm{g} / \mathrm{ml})\end{array}$ & $\begin{array}{c}\text { Inoculum added } \\
(\mu \mathrm{l})\end{array}$ & Observation & $\begin{array}{c}\mathrm{MIC} \\
\mu \mathrm{g} / \mathrm{ml}\end{array}$ \\
\hline 1 & 1 & 512 & 10 & $\mathrm{NG}$ & \\
2 & 1 & 256 & 10 & NG & \\
3 & 1 & 128 & 10 & $\mathrm{NG}$ & \\
4 & 1 & 64 & 10 & $\mathrm{G}$ & \\
5 & 1 & 32 & 10 & $\mathrm{G}$ & \\
6 & 1 & 16 & 10 & $\mathrm{G}$ & 128 \\
7 & 1 & 8 & 10 & $\mathrm{G}$ & \\
8 & 1 & 4 & 10 & $\mathrm{G}$ & \\
9 & 1 & 2 & 10 & $\mathrm{G}$ & \\
10 & 1 & 1 & 10 & $\mathrm{G}$ & \\
$\mathrm{C}$ & 1 & 512 & 00 & $\mathrm{G}$ & \\
$\mathrm{C}$ & 1 & 0 & 10 & $\mathrm{G}$ & \\
$\mathrm{CM}_{\mathrm{M}}$ & 1 & 0 & 00 & $\mathrm{NG}$ & \\
\hline
\end{tabular}

G=Growth; NG= No Growth; No. of cells: $10^{7} \mathrm{cell} / \mathrm{s} / \mathrm{ml}$ 


\section{Brine shrimp lethality bioassay:}

The pure compound TC-1 showed positive result in brine shrimp lethality bioassay. To determine the toxic effect of TC-1, medium lethal concentration $\left(\mathrm{LC}_{50}\right)$ of brine shrimp lethality has been measured and it is found to be $9.34 \mu \mathrm{g} / \mathrm{ml}$, which is obtained from a plot of percentage of mortality versus concentration on the graph, produced as approximate linear correlation between them (Fig.1).

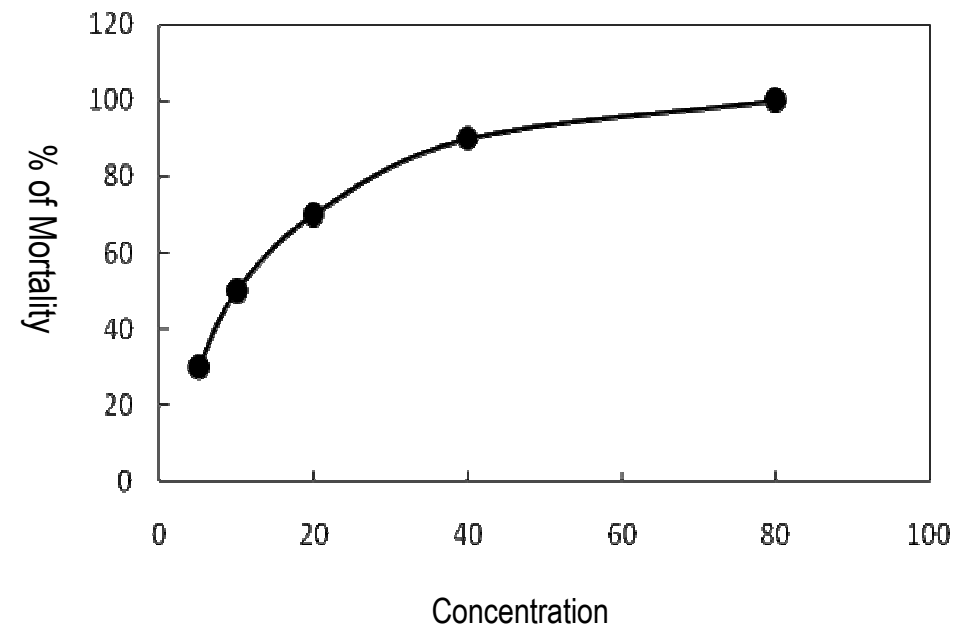

Fig.1. $\mathrm{LC}_{50}$ of the pure compound TC-1 against brine shrimp nauplli

In this bioassay, the mortality rate of brine shrimp is found to increase with the increase in concentration of the compound so is to observe that there is a positive correlation between brine shrimp toxicity and cytotoxicity. The very low value of $L C_{50}$ indicates the high cytotoxic effect of TC-1. The results of brine shrimp lethality of the compound TC-1 is given in the table 5 .

Table 5. Results of TC-1 on brine shrimp lethality bioassay

\begin{tabular}{|c|c|c|c|c|c|}
\hline $\begin{array}{c}\text { Concentration } \\
\mu \mathrm{g} / \mathrm{ml}\end{array}$ & $\begin{array}{l}\text { No. of nauplii } \\
\text { taken }\end{array}$ & $\begin{array}{l}\text { No. of nauplii } \\
\text { alive }\end{array}$ & $\begin{array}{l}\text { No. of nauplii } \\
\text { died }\end{array}$ & $\%$ of mortality & $\begin{array}{l}\mathrm{LC}_{50} \\
\mu \mathrm{g} / \mathrm{ml}\end{array}$ \\
\hline 5 & 10 & 7 & 3 & 30 & \\
\hline 10 & 10 & 5 & 5 & 50 & \\
\hline 20 & 10 & 3 & 7 & 70 & 9.34 \\
\hline 40 & 10 & 1 & 9 & 90 & \\
\hline 80 & 10 & 0 & 0 & 100 & \\
\hline
\end{tabular}

\section{Conclusion}

The plant Tinospora cordifolia belonging to Menispermaceae family was studied. From the combined fractions A-F, only one compound (TC-1) was isolated and purified. From the different spectral evidences, it has been concluded that the compound TC-1 is an alkaloid. The pure compound TC-1 showed activity against some bacteria and fungi. The minimum inhibitory concentration of this compound was determined. It was also showed significant activity against the brine shrimp nauplii. The plant is being used as folk medicine 
in the treatment of diabetes, jaundice and skin diseases but unfortunately in this study no such compounds were identified and no such experiment was done for the treatment of those diseases and hence further study on this plant is to be extended.

\section{References}

Bauer AW, Kirby WM, Sherris JC, Truck M. 1966. Antibiotic susceptibility testing by standardized single disc method. Am J Clin Pathol 45,493-496.

Burger A. 1960. Medicinal Chemistry. Inter Science Publishers, New York, 4-6, 12.

Finar IL. 1975. Organic Chemistry. $5^{\text {th }}$ ed. Longman, Singapore. 767-788 pp.

Fuller HJ, Carothers ZB. 1967. The Plant World. 4th ed.; Holt, Rinehart and Winston Inc. 1-4.

Gupta SS, Verma SCL, Garg VP, Mahesh Rai. 1967. Antidiabetic effects of Tinospora cordifolia. Effect on fasting blood sugar level, Glucose tolerance and adrenaline induced hyperglycemia. Ind Jour Med Res 55, 733-745.

Hesse MF, Gemenden CW, Joshi BS, Taylor WI and Schmid H. 1966. Helvitica Chemical Acta 49, 1173. http://dx.doi.org/10.1002/hlca.19660490314

Kirtikar KR, Basu BD, editors. Indian Medicinal Plants, Vol 1. 2nd ed. New Connaught Place, Dehra Dun: M/S Bishen Singh, Mahendra Pal Singh; 1975.

Laetsch WM. 1979. Plants: Basic Concepts in Botany. Little and Brown Co. Ltd., Canada. 159.

Lewington A. 1990. Plants for People. Natural history museum, London. 135-136.

Mahajan VR, Jolly Cl. 1985. A new hypoglycaemic agent from Tinospora cordifolia: Miers. Indian Drugs. 23(2). 119-120.

Muller JM, Schlitter E, Bein HJ, 1952. Reserpin, der sedative Wirkstoff aus Rauwolfia serpentina Benth. Experientia 8:388-391. http://dx.doi.org/10.1007/BF02174406

Nadkarni KM, Nadkarni AK. 1976. Indian Materia Medica. 3rd ed, Popular Prakashan Ltd.

Rao PS, Venkaiah K, Murali V, Satyanarayana VV. 2000. Macro-propagation of some important medicinal plants Andhra Pradesh. Indian Forester. 126 (12), 1265-1269.

Reiner R. 1982. Antibiotics: An Introduction. F Hoffmamm-La Roche and Co.Ltd. Switzerland, 21-27. 